the education of chemists under the headings of chemistry in schools, chemistry at tho university and the technical college, the training of chemists and chemical technicians engaged in industry, and the recruitment and training of teachers of chemistry.

The report has little to say about the inherent value of science as part of a liberal education, con. fining itself to the bare assertion that the study of science is of direct cultural importance. This aspect could usefully have been treated more fully, for even to-day it remains true that in a great many schools science is regarded as on a lower educative plane than the so-called humanities. A strong lead from the British Association of Chemists would have found wide support from science masters and mistresses, and since the fundamental education of chemists is given in the schools, the tone should have been pitched high from the start. The report does, however, make many valuable observations on school science, especially the remark that there is sometimes too much insistence on 'the spirit of science' and too little on providing in an assimilable form an essential basis of facts and their relationship. This is a fully justified charge : the pendulum has, indeed, swung to the opposite extreme from the old South Kensington days, and university chemistry teachers have good reason to complain of the lack of factual knowledge shown by freshmen. Though the report does not specifically refer to it, one contributory cause of this situation, so far as chemistry is concerned, is the neglect of qualitative analysis in the schools : analysis admittedly requires a great deal of time, but it does make the student familiar with the materials of his craft.

On types of school, the report refers to the suggestion in the White Paper on Education that at eleven, and at thirteen, pupils should be allocated to one of the three kinds of secondary school-grammar, modern or technical. This suggestion is regarded as unsound, because no preference is shown by most pupils at these ages ; instead, the Committee recommends that the three proposed types of school should be divisions of one multilateral institution under the general control of the same board of governors and arranged if possible on the house system. The chief advantage claimed for this system is a social one; it would help to prevent the development of superiority or inferiority complexes surrounding the type of child in a particular grade of school. The Committee agrees that there is a case for grouping pupils at about the age of thirteen into classes of differing intellectual abilities, but makes the very sound point that this grouping should be such as to allow those who learn quickly to make more rapid progress in a common curriculum than to divide children into classes taking widely different courses.

On the question of external school examinations, the Committee feels that some such test at School Certificate age should be maintained, since industry and society require some datum line on which they can base an initial estimate of educational attainment, and an internal standard must inevitably vary from school to school. The test should, however, be conducted in such a way as to yield an estimate of general intelligence rather than of an ability to reproduce set problems and books. After the school minimum leaving age, the Committee recommends for all pupils the continuation of a general course in certain compulsory subjects, including science, with a choice of others, such as languages, handicrafts, and so on. The basic subjects common to all would be
English, science, mathematics, a modern language, history and geography, with the addition of Latin for potential science specialists if it has not been studied previously.

As to the Higher Certificate, the Committee feels, like so many of us, that the whole basis of the examination should be broadened, and that the certificate should not exempt the student from the first-year course at a university. Similarly, scholarship examinations should not be tests to discover how far candidates have already progressed towards their degree, but should be a means by which those most capable of profiting by further education on more specialized lines may be selected.

At the university and technical college, the report continues, the science student must have time to make contact with students in other faculties and sufficient leisure to follow some cultural interests. This would probably involve an increase from three years to four years in the normal pass degree course, and is particularly necessary in chemistry if the proper background to the subject is to be imparted.

Further suggestions by the Committee include closer co-operation between the universities and the chemical industry, a modification in the conditions of military service for undergraduates, the formation of training centres for technical grades, better prospects for junior employees, an improved financial standard of remuneration for chemists and the encouragement of well-qualified teachers. The report ends with an appeal to all the organisations now representing the craft of chemistry to make a common approach to the whole subject.

\section{E. J. HolmyaRd}

\section{ECHINODERM FAUNA OF AUSTRALIA}

\section{$\mathrm{D}^{\mathrm{R}}$} R. HUBERT LYMAN CLARK'S large work, "Echinoderms from Australia", was reviewed in Nature of September 24, 1938. That review and the obituary notice of Dr. Clark in Nature of September 20, 1947, show how many and how important were his contributions to the knowledge of Australian echinoderms. He had made them his peculiar province ; it is fitting that they should be the subject of his chef-d'cuvre, "The Echinoderm Fauna of Australia : its Composition and its Origin"*, which was published in 1946 and has now reached Great Britain. For it he received on his daathbed the award of the Australian Clarke Medal.

Part 1, which is by far the greater part of the volume, is an account of all the echinoderms, living or extinct, which are known from Australia. There are keys to all orders, families, genera and species; and, under each species-and there are nearly nine hundred of them-notes on synonymy, range, occurrence, habitat, habits, colour, variation and food so far as they are known. There are no illustrations, since nearly all the species have been figured elsewhere, and references to those figures are given.

Part 2 is a discussion of the composition and origin of the Australian echinoderm fauna. Its most characteristic feature is the predominance of East Indian forms and influences, so that there can be no doubt it is derived from there. It appears to have

* Carnegie Institution of Washington, Publication No. 566. The Echinoderm Fauna of Australia ; its Composition and its Origin. By Hubert Lyman Clark. Pp. iv +567. (Washington, D.C.: Carnegie Institution, 1946.) 4 dollars. 
come along two paths, one on either side of the landbridge which once spanned what is now the Torres Strait; for the faunas of the north coast and of east Queensland bear each a different facies, having not yet completely commingled. The farther away one goes from Torres Strait, whether south by Queensland and west along the Bight, or north by Darwin and so around to Perth, the more characteristic the fauna becomes, until in the south-western corner it is nine-tenths endemic.

The conclusion that the Australian echinoderm fauna is East Indian in origin is preceded by successive and detailed comparisons with the echinoderm faunas of all surrounding lands-of Antarctica, Kerguelen, Mauritius, South Africa and so on north-about to New Zealand. Dr. Clark believed that because of their "relatively sedentary habits, their aversion to fresh or even brackish water, the brevity or complete absence of a free-living larval life, and the usually small bathymetric range, echinoderms are remarkably suitable material for studying changes in shore line or the relation of land masses to each other". Where in distant faunas he finds similarities to that of Australia he attributes them, for the most part, to a common source in the East Indian fauna. A number of perplexing forms, like, for example, the sea-urchin Dermechinus, which occurs off the southern tips of America, Africa and Australia, cannot be so explained; but Dr. Clark concludes "that only a desperate desire to validate the Wegener hypothesis can find in the echinoderm fauna of Australia any evidence that it is at all closely related to that of South Africa or even of Now Zealand".

D. DilWYN JOHN

\section{TOWARDS AN INTERNATIONAL PHARMACOPCIA}

$\mathrm{T}$ HE first meeting was held at Geneva during October 13-17 of the Expert Committee on the Unification of Pharmacopoeias of the World Health Organisation. There were present Prof. H. Baggesgaard Rasmussen (Denmark), Prof. E. Fullerton Cook (United States), Prof. I. R. Fahmy (Egypt), and Dr. C. H. Hampshire (Great Britain); Prof. R. Hazard (France) was prevented by illness from attending. The members were welcomed, in the name of the Executive Secretary, by Dr. R. Gautier, who said that the duties of the Committee would be to continue the work on the unification of pharmacopoias which had been begun by the Technical Commission of Pharmacopcial Experts of the League of Nations. Dr. C. H. Hampshire was elected chairman.

The Committee accepted the general principles expressed in the Interim Report of the previous Commission published in 1945, and approved the monographs contained therein, subject to consideration of any comments which might be received later. The intention that the recommendations of the Committee should take the form of an International Pharmacopoia was approved, the scope to be limited in the first place to drugs considered to be essential in medical practice. It was understood that such an International Pharmacopœia could have no authority in any country until it had been adopted by that country.

A list of 534 drugs was considered and 244 were selected for immediate attention. It was decided that monographs on the drugs for which the Committee on Biological Standardization had provided standards should be included. Thirty draft mono. graphs were completed, making with those in the interim report a total of seventy-two.

The preparation of drafts of monographs, general notices and appendixes, and of reports on special subjects was allocated among the members present, who also undertook the necessary experimental work. Arrangements were made for special reports on such subjects as alkaloidal assays, boiling points and melting points, fineness of powders, and the sterilization of injectable materials.

In view of the fact that the place of galenicals in medicine had been largely taken by the new synthetics, alkaloids and injectable materials, the Committe decided not to re-establish the Reference Sub-Committee on Galenical Pharmacy, appointed by the previous Commission. The possibility of establishing an international procedure for naming new drugs at an early stage of their introduction into medicine, and the standardization of surgical ligatures, sutures and dressings, were also discussed and reserved for future consideration.

In view of the volume of work to be undertaken and of the necessity for widening the international basis of the work, the Committee recommended that at least three additional members should be appointed and that a unified secretariat with specialized staff should be formed.

\section{FORTHCOMING EVENTS}

Monday, January 5

SOCIETY of CHEMICAL INDUSTRY (at the Chemical Society, Burlington House, Piccadilly, London, W. 1), at, 6.30 p.m.-Mr. H. J. Bunker: "Some Scientific Aspects of Beer".

\section{Tuesday, January 6}

INSTITUTION OF CIviL ENGINERRS (at Great George Street, London, S.W.1), at 5.30 p.m.-Mr. Clifford Heyes and Mr. J. Brierley : "Airfleld Lighting".

INSTITUTION OF MECHANICAL ENGINERRS, AUTOMOBILE DIVISION (at Storey's Gate, St. James's Park, London, S.W.1), at 6 p.m.Capt. G. T. Smith-Clarke : Chairman's Address.

INSTITUTE OF WELDING, MANCHESTER AND DISTRIOT BRANCH (in the Reynolds Hall, College of Technology, Manchester), at 7 p.m.Mr. S. W. Carpenter: "Automatic Welding".

Wednesday, January 7

ILLUMINATING ENGINEERing SOCIETT, MANCHESTER CENTRE (joint meeting with the ASSOCIATION OF PUBLIC IIGHTING ENGINEERS, in the Reynolds Hall, College of Technology, Manchester), at 6 p.m.Mr. E. J. Stewart: "The Lighting of Housing Estates".

\section{Thursday, January 8}

Phystcal Soctety, Aoodstics Group (at the National Hospital, Queen Square, London, W.C.1), at 4.30 p.m.-Prof. H. Hartridge, F.R.S.: "The Use of Supersonic Sound by Animals"; Dr. C. S. Hallpike and Miss M. R. Dix: "Pure-Tone Audiometry in Young Children, a New Technique" (Film and Demonstration); Dr. Dennis Fry : "Tone Deafness".

Chemical Societr, Manchester Section (joint meeting with the LOCAI SECTIONS of the SOCIETY OF CHEMICAL INDUSTRY and the ROOAI INSTIPUTE OF CHEMISTRY, in the Chemistry Lecture Theatre, ROYAT INSTIPUTE of CHEMISTR Y, in the Chemistry Lecture Theatre,
The University, Manchester), at 6.30 p.m.-Dr. M. P. Applebey: "Crystallisation of Fertilisers",

INSTITOTION OF CIVIL ENGINERRS, NORTH-WRSTERN ASSOCIATION (at the Engineers' Club, Albert Square, Manchester), at 6.30 p.m.Mr. W. J. O. Scott: "Roads and their Riding Qualities".

CHEMmCAL SOCIETY (at Burlington House, Piccadilly, London, W.1), at 7.30 p.m. - Prof. T. P. Hilditch, F.R.S.: "Structural Relationships in the Natural Unsaturated Higher Fatty Acids".

\section{Friday, January 9}

TEXThe Insmitume (at 16 St. Mary's Parsonage, Manchester), at 1 p.m.-Dr. A. Roberts : "Education for Management in the Textile Industry".

OIr AND COLOJR CHFMists' Association, MaNCHESTER SkCtion (at the Engineers' Club, Albert Square, Manchester), at 2 p.m.-Mr. Styrene Co-Polymers". 